Testing and Performance Verification of a High Bypass Ratio Turbofan Rotor in an Internal Flow Component Test Facility

Dale E. Van Zante, Gary G. Podboy, Christopher J. Miller, and Scott A. Thorp Glenn Research Center, Cleveland, Ohio 


\section{NASA STI Program . . . in Profile}

Since its founding, NASA has been dedicated to the advancement of aeronautics and space science. The NASA Scientific and Technical Information (STI) program plays a key part in helping NASA maintain this important role.

The NASA STI Program operates under the auspices of the Agency Chief Information Officer. It collects, organizes, provides for archiving, and disseminates NASA's STI. The NASA STI program provides access to the NASA Aeronautics and Space Database and its public interface, the NASA Technical Reports Server, thus providing one of the largest collections of aeronautical and space science STI in the world. Results are published in both non-NASA channels and by NASA in the NASA STI Report Series, which includes the following report types:

- TECHNICAL PUBLICATION. Reports of completed research or a major significant phase of research that present the results of NASA programs and include extensive data or theoretical analysis. Includes compilations of significant scientific and technical data and information deemed to be of continuing reference value. NASA counterpart of peer-reviewed formal professional papers but has less stringent limitations on manuscript length and extent of graphic presentations.

- TECHNICAL MEMORANDUM. Scientific and technical findings that are preliminary or of specialized interest, e.g., quick release reports, working papers, and bibliographies that contain minimal annotation. Does not contain extensive analysis.

- CONTRACTOR REPORT. Scientific and technical findings by NASA-sponsored contractors and grantees.
- CONFERENCE PUBLICATION. Collected papers from scientific and technical conferences, symposia, seminars, or other meetings sponsored or cosponsored by NASA.

- SPECIAL PUBLICATION. Scientific, technical, or historical information from NASA programs, projects, and missions, often concerned with subjects having substantial public interest.

- TECHNICAL TRANSLATION. Englishlanguage translations of foreign scientific and technical material pertinent to NASA's mission.

Specialized services also include creating custom thesauri, building customized databases, organizing and publishing research results.

For more information about the NASA STI program, see the following:

- Access the NASA STI program home page at http://www.sti.nasa.gov

- E-mail your question via the Internet to help@ sti.nasa.gov

- Fax your question to the NASA STI Help Desk at $443-757-5803$

- Telephone the NASA STI Help Desk at 443-757-5802

- Write to: NASA Center for AeroSpace Information (CASI) 7115 Standard Drive Hanover, MD 21076-1320 


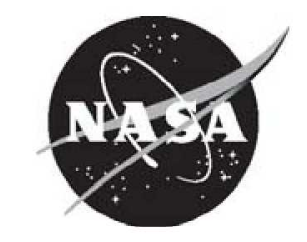

\section{Testing and Performance Verification of a High Bypass Ratio Turbofan Rotor in an Internal Flow Component Test Facility}

Dale E. Van Zante, Gary G. Podboy, Christopher J. Miller, and Scott A. Thorp Glenn Research Center, Cleveland, Ohio

Prepared for

Turbo Expo 2007

sponsored by the American Society of Mechanical Engineers

Montreal, Canada, May 14-17, 2007

National Aeronautics and

Space Administration

Glenn Research Center Cleveland, Ohio 44135 


\section{Acknowledgments}

Thanks to Rod Chima for doing the exit diffuser design, Tony Strazisar for assisting with the flow conditioning design references, Sue Prahst for online data acquisition software assistance, and Ed Envia for the broadband noise predictions. Thanks also to an excellent test cell crew: Tom Jett, Rick Brokopp, Bruce Wright, Helmi Abulaban, and Jerry Buchar. This work was supported by the NASA Quiet Aircraft Technology program, Joe Grady manager.

This work was sponsored by the Fundamental Aeronautics Program at the NASA Glenn Research Center.

Level of Review: This material has been technically reviewed by technical management.

Available from

NASA Center for Aerospace Information 7115 Standard Drive

Hanover, MD 21076-1320
National Technical Information Service 5285 Port Royal Road Springfield, VA 22161

Available electronically at http://gltrs.grc.nasa.gov 


\title{
Testing and Performance Verification of a High Bypass Ratio Turbofan Rotor in an Internal Flow Component Test Facility
}

\author{
Dale E. Van Zante, Gary G. Podboy, Christopher J. Miller, and Scott A. Thorp \\ National Aeronautics and Space Administration \\ Glenn Research Center \\ Cleveland, Ohio 44135
}

\begin{abstract}
A $1 / 5$ scale model rotor representative of a current technology, high bypass ratio, turbofan engine was installed and tested in the W8 single-stage, high-speed, compressor test facility at NASA Glenn Research Center (GRC). The same fan rotor was tested previously in the GRC 9x15 Low Speed Wind Tunnel as a fan module consisting of the rotor and outlet guide vanes mounted in a flight-like nacelle. The W8 test verified that the aerodynamic performance and detailed flow field of the rotor as installed in W8 were representative of the wind tunnel fan module installation. Modifications to W8 were necessary to ensure that this internal flow facility would have a flow field at the test package that is representative of flow conditions in the wind tunnel installation. Inlet flow conditioning was designed and installed in W8 to lower the fan face turbulence intensity to less than 1.0 percent in order to better match the wind tunnel operating environment. Also, inlet bleed was added to thin the casing boundary layer to be more representative of a flight nacelle boundary layer. On the 100 percent speed operating line the fan pressure rise and mass flow rate agreed with the wind tunnel data to within 1 percent. Detailed hot film surveys of the inlet flow, inlet boundary layer and fan exit flow were compared to results from the wind tunnel. The effect of inlet casing boundary layer thickness on fan performance was quantified. Challenges and 'lessons learned' from testing this high flow, low static pressure rise fan in an internal flow facility are discussed.
\end{abstract}

\section{Introduction}

Noise from turbofan engines used on commercial aircraft is a major concern for aircraft owners and airport operators. The Federal Aviation Administration in the United States and the International Civil Aviation Organization, the international organization that coordinates environmental noise issues, have issued increasingly more stringent aircraft noise regulations and have curtailed flight operations for aircraft, forcing aircraft and engine manufacturers to pursue quieter aircraft designs. As part of the overall NASA program to reduce total aircraft noise, technical efforts were initiated with the major U.S. aircraft engine manufacturers to investigate noise reduction technologies for current technology turbofan engines. Through the use of acoustic liners and aerodynamic design changes, the tone noise generated by commercial turbofan engines has been reduced significantly. To achieve any further noise reduction, the broadband noise generated by the fan must be reduced. The aerodynamic sources for broadband noise production in fans (especially transonic fans) are not well understood.

NASA's Quiet Aircraft Technology (QAT) program sponsored the Source Diagnostic Test (SDT) to identify broadband noise sources in transonic fans and to develop prediction tools. This SDT hardware underwent extensive performance and acoustic testing in the GRC 9x15 Low Speed Wind Tunnel (LSWT) as a stage and as rotor alone. An overview of the SDT fan module hardware, aerodynamic performance, and acoustic test results are in References 1 and 2. The fan module is shown in its acoustic configuration in Figure 1 installed in the $9 \times 15$ LSWT.

While performance and acoustic data are useful, detailed internal flow field measurements are required to identify noise sources and provide information for noise prediction codes. Hotwire/film Anemometry and Laser Doppler Velocimetry measurements were acquired during SDT entry 1 in the $9 \times 15$ (Ref. 1). Particle Image Velocimetry (PIV) measurements were acquired of the fan flow field during the $2^{\text {nd }}$ SDT entry in the $9 \times 15$. All of the above mentioned measurement techniques are challenging, time consuming and, therefore, costly in a large wind tunnel facility. For broadband noise source identification indirect measures such as turbulence intensity can be used to identify regions of noise production and thus the test need not occur in an anechoic facility such as the $9 \times 15$ LSWT. Additionally, the use of flight-like fan module configurations is necessary for acoustic testing, but these configurations also restrict the types of hardware modifications that are possible for implementing advanced internal measurement techniques. Thus, for cost and hardware flexibility reasons, the use of the W8 component test facility for noise source identification was investigated.

The W8 facility has a long history of detailed flow measurements, including the NASA Fan 67 shock location study (Ref. 3) and the ASME Rotor 37 test case data (Ref. 4). The facility is well suited for detailed measurements because the test package is enclosed in a research type casing instead of a flight like nacelle. The heavy, modular, and easily reconfigurable W8 casing provided ample structural integrity for actuators, optical access windows, etc. For non-intrusive optical measurements the flow seeding in W8 (unlike the 9x15 LSWT) is internal to the experiment package. This allows 


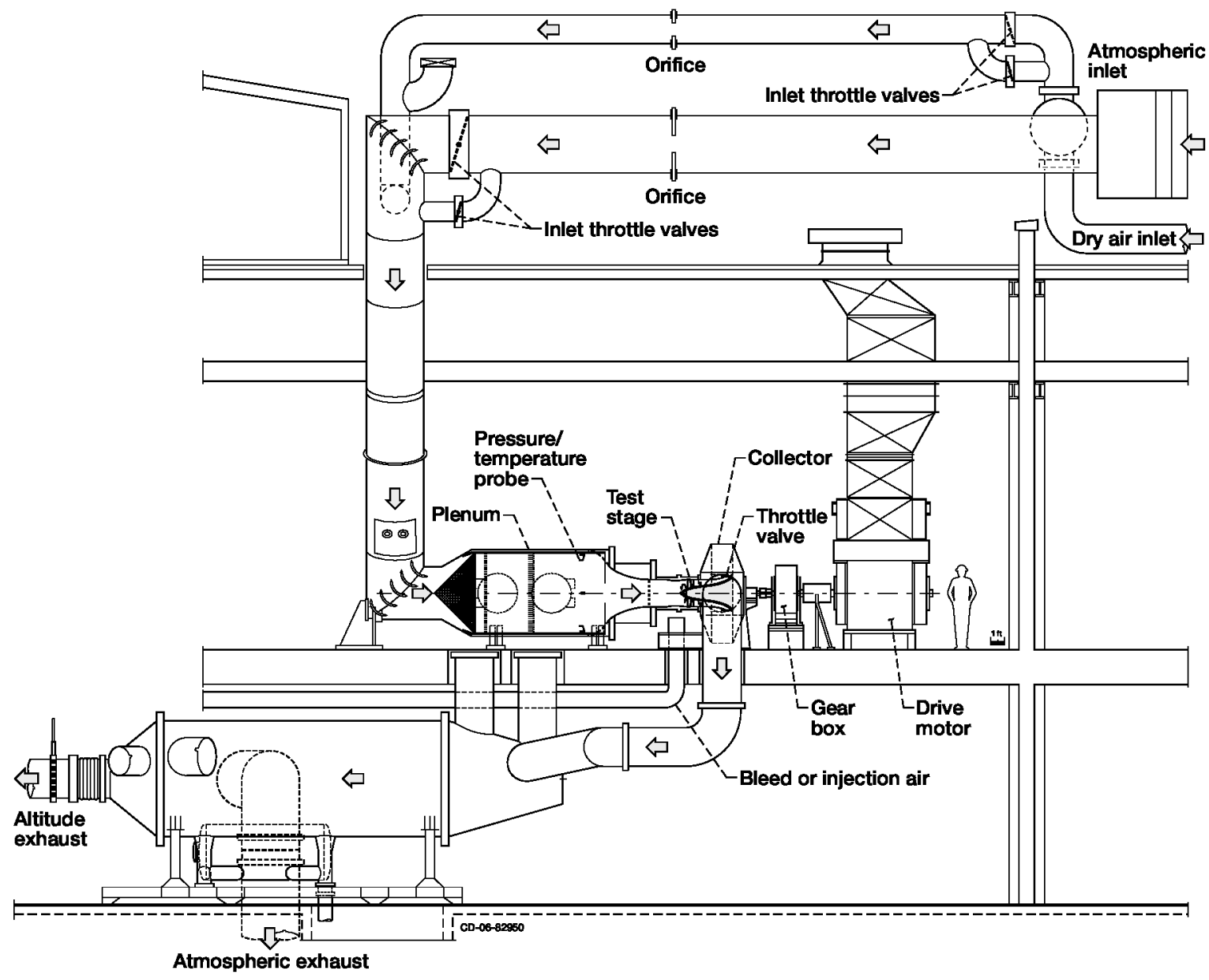

Figure 2.-Schematic of the W8 single-stage axial compressor test facility.

test cell floor to a large spray cooler plenum where the exhaust air is piped to either the atmospheric or altitude exhaust system. The fan hardware is driven by a $5.22 \mathrm{MW}(7000 \mathrm{hp})$ variable speed electric motor. The driveline is capable of $20240 \mathrm{rpm}$ and has a shaft attachment scheme similar to the 9x15 LSWT fan drive rig.

Modifying an internal flow facility so that conditions at the fan module are representative of the wind tunnel installation is challenging. Changes were made in four main areas: (1) inlet flow conditioning, (2) casing boundary layer thickness control, (3) the exit diffuser/throttle valve geometry, and (4) the system for mass flow measurement. Each modification is discussed in detail next.

\section{Inlet Flow Conditioning}

The original W8 plenum had wedges transverse to the flow which were intended to force the flow from the $1.22 \mathrm{~m}$ diameter inlet pipe to fill the $1.83 \mathrm{~m}(6 \mathrm{ft})$ diameter inlet plenum. Single element hot wire anemometer measurements of the flow field near the bellmouth entrance revealed turbulence intensities of greater than 10 percent, see Table 4 .
Particle Image Velocimetry measurements of the flow field directly upstream of a transonic compressor rotor showed a turbulence intensity of 5 percent, even after the flow had accelerated through the bellmouth. Discussions with industry partners indicated that the turbulence intensity at the fan rotor face must be at or below 1 percent to be acceptable.

TABLE 4.-W8 PLENUM TURBULENCE INTENSITY

\begin{tabular}{|c|c|c|}
\hline $\begin{array}{c}\text { Flow rate, } \\
\mathrm{kg} / \mathrm{s}(\mathrm{lb} / \mathrm{s})\end{array}$ & $\begin{array}{c}\text { Original flow } \\
\text { conditioning, } \\
\text { Tu\% }\end{array}$ & $\begin{array}{c}\text { New flow } \\
\text { conditioning } \\
\text { installed, } \\
\text { Tu\% }\end{array}$ \\
\hline $13.6(30.0)$ & 15.6 & 1.4 \\
$16.4(36.1)$ & 14.2 & --- \\
$18.1(40.0)$ & --- & 1.5 \\
$27.2(60.0)$ & -- & 1.4 \\
$31.0(68.4)$ & -- & 1.5 \\
\hline
\end{tabular}

A series of flow conditioning elements, shown schematically in Figure 3, were designed and installed based on recommendations in References 5,6, and 7. The elements 


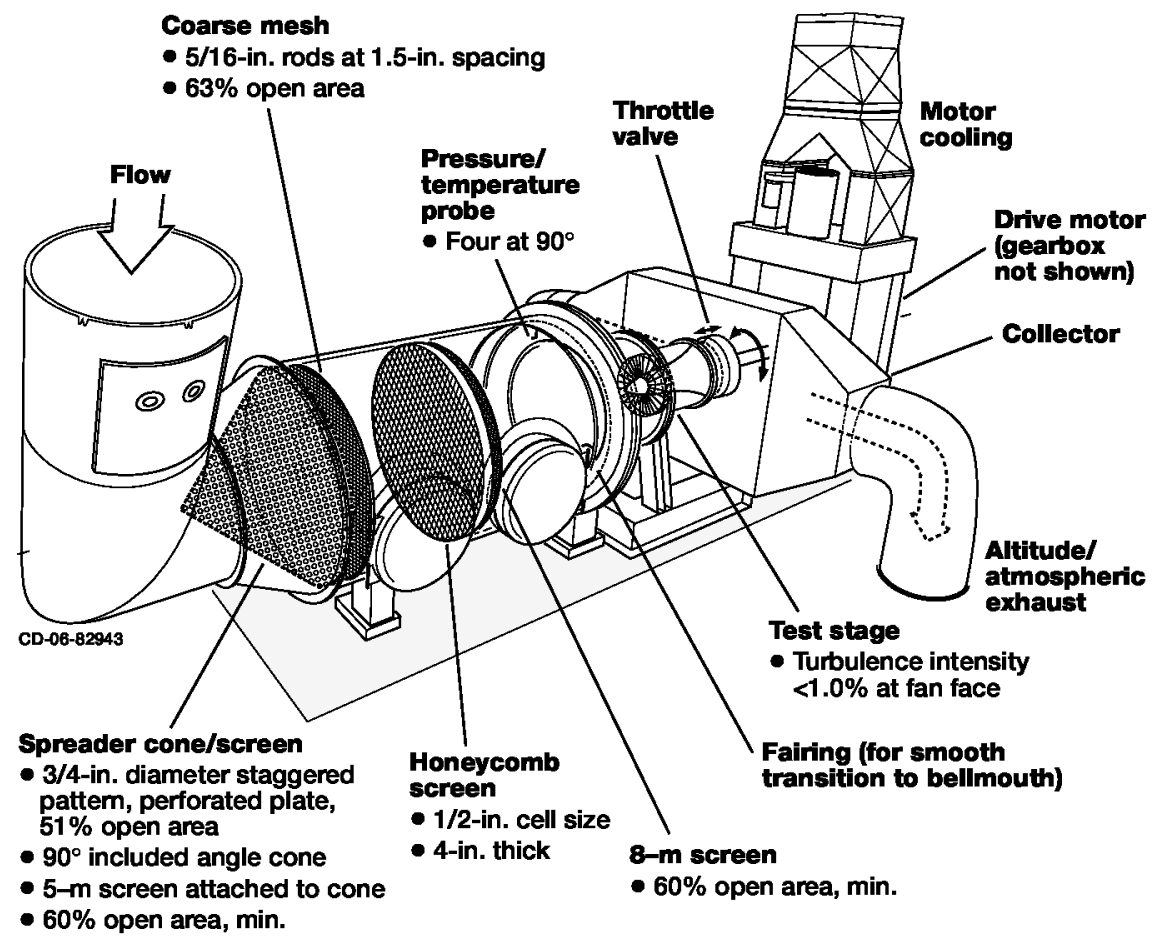

Figure 3.-W8 inlet plenum flow conditioning elements.

consist of a spreader cone+screen combination at the plenum entrance, a coarse "chopper" screen, and a final honeycomb+fine screen combination. Details are in Table 5. With the flow conditioning installed the turbulence intensity decreased to $\leq 1.5$ percent at the bellmouth entrance.

TABLE 5.-FLOW CONDITIONING ELEMENTS.

\begin{tabular}{|l|l|}
\hline Spreader cone/screen & $\begin{array}{l}\text { 3/4 in. diameter staggered pattern } \\
\text { perforated plate, 51\% open area } \\
5 \mathrm{M} \text { screen }\end{array}$ \\
\hline Coarse 'chopper' screen & $\begin{array}{l}5 / 16 \text { in. rods at } 1.5 \text { in. spacing, 63\% } \\
\text { open area }\end{array}$ \\
\hline Honeycomb/fine screen & $\begin{array}{l}1 / 2 \text { in. cell size, } 4 \text { in. thick } \\
8 \mathrm{M} \text { screen on downstream side }\end{array}$ \\
\hline
\end{tabular}

The fan flowpath was then installed and the altitude exhaust system was used to draw air through the facility to obtain two component hot film measurements near the fan rotor location. The survey location is shown in Figure 5. The casing boundary layer bleed was not used during this testing. Figure 4 shows spanwise profiles of turbulence intensity for three flow rates. The highest flow rate is the maximum achievable without the fan rotor installed and is representative of the Cutback fan operating speed flow rate. The turbulence intensity is less than 1 percent outside of the casing boundary layer region for all three flow rates. The goal of turbulence intensities less than 1 percent in the core flow regions was achieved with the addition of flow conditioning. The use of boundary layer bleed will further reduce the radial extent of the high turbulence region on the casing.

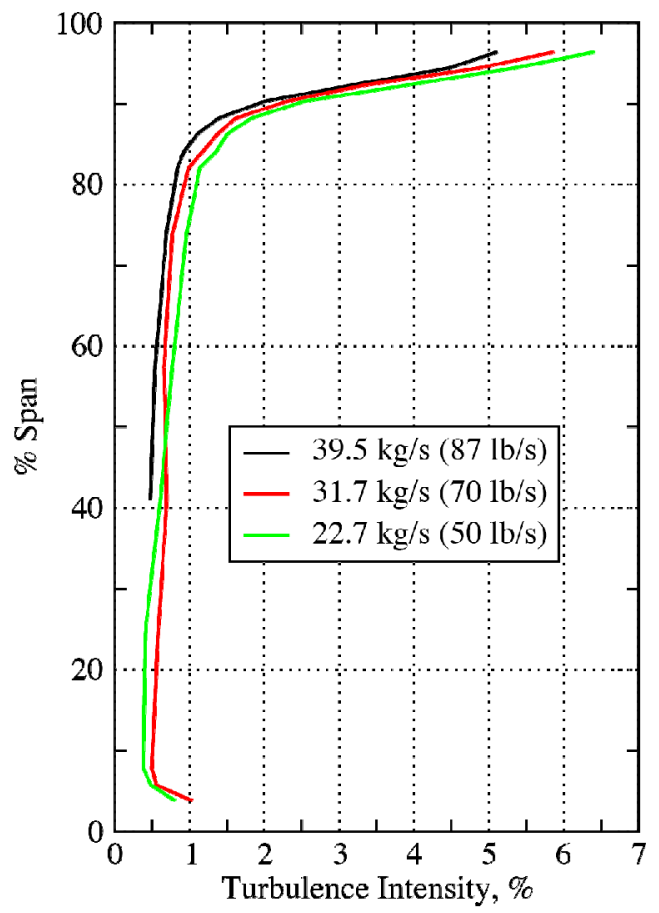

Figure 4.-Spanwise profiles of turbulence intensity near the fan rotor location in W8 after installation of flow conditioning elements. 
A schematic cross section of the fan module from the $9 \times 15$ LSWT test is shown in Figure 6. For this flight-like inlet the boundary layer begins at the stagnation point outside the inlet lip and remains relatively thin to the fan face. For an internal flow facility like W8 the boundary layer growth begins in the inlet pipe on the test cell roof. The inlet flow conditioning and bellmouth contraction will act to minimize the boundary layer thickness but additional flow control is necessary to make the W8 boundary layer at the fan face as similar to the flight like inlet as possible.

The W8 flow path from the bellmouth to the throttle valve is shown in Figure 5. The flow path contour from the inlet throat to the nozzle highlight matched the Rotor Alone Nacelle (RAN) flow path geometry from the $9 \times 15$ test. From the throat forward, the geometry was mirrored and a flat added at the throat location with a bleed slot. Bleed rates in W8 were $0.68 \mathrm{~kg} / \mathrm{s}(1.5 \mathrm{lb} / \mathrm{s})$ for 61.7 percent $\mathrm{Nc}, 0.59 \mathrm{~kg} / \mathrm{s}(1.3 \mathrm{lb} / \mathrm{s})$ for 87.5 percent $\mathrm{Nc}$, and $0.54 \mathrm{~kg} / \mathrm{s}(1.2 \mathrm{lb} / \mathrm{s})$ for 100 percent $\mathrm{Nc}$. Surveys of the boundary layer were done at the same axial location relative to the fan face in both W8 and the $9 \times 15$. Figure 7 shows a comparison of boundary layer thickness; normalized total pressure in W8 with casing bleed and normalized velocity in the SDT inlet. The W8 inlet shows a thicker casing boundary layer and a 'secondary' boundary layer which is a remnant of the plenum boundary layer.

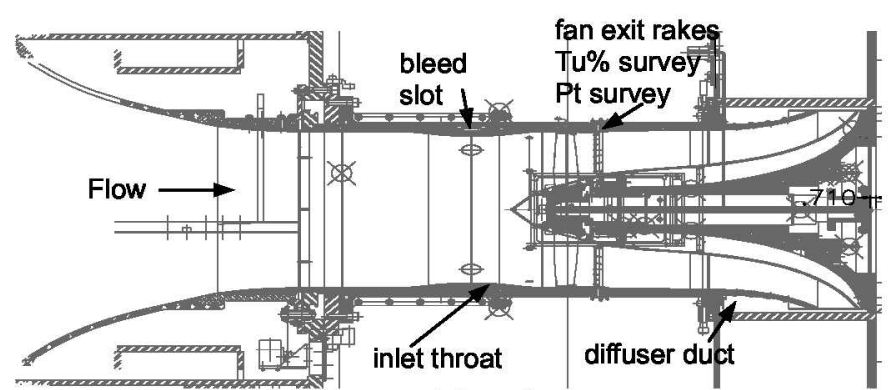

Figure 5.-Cross section of SDT fan installation in W8.

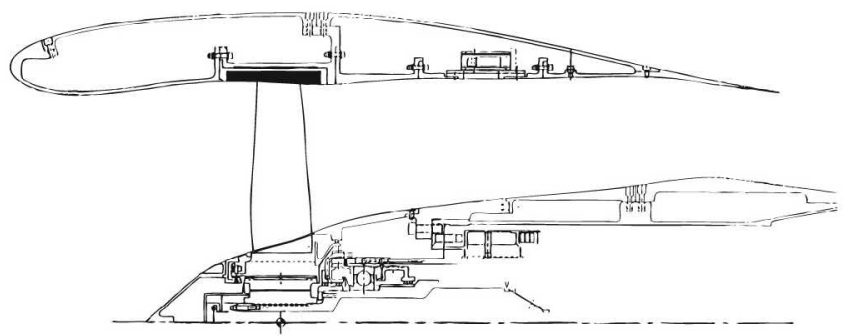

Figure 6.-Schematic of fan module from 9x15 LSWT in rotor alone nacelle (RAN) configuration.
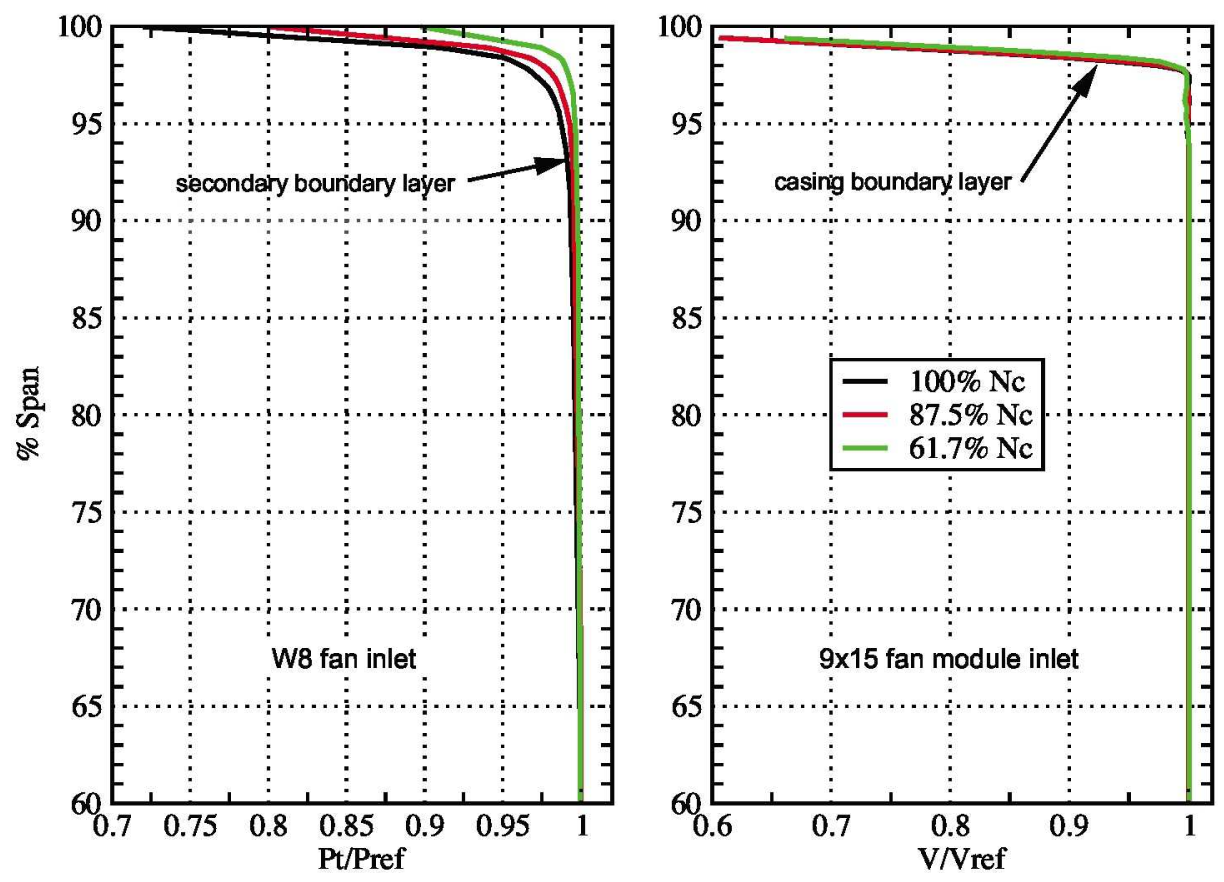

Figure 7.-Comparison of casing boundary layer profiles from the W8 inlet (Pt/Pref) and the flight like 9x15 fan module inlet (VNref) at the three fixed nozzle area operating points. 
Due to pressure losses in the bleed system, the bleed rates were not high enough to thin the boundary layer to match the wind tunnel installation. The thicker casing boundary layer in W8 results in a lower area average total pressure at the fan face. In the 9x15 the inlet reference conditions for calculating aeroperformance for the fan module come from a cruciform rake mounted to the tunnel floor and, in W8, from inlet plenum total condition probes. If no correction is made to the W8 inlet reference conditions, the fan performance in W8 will be unfairly decremented due to the additional inlet loss. With some assumptions, the SDT inlet profile was converted to total pressure. The area average total pressure was computed and assumed representative of the difference in loss at the fan face. The inlet reference condition for W8 was then adjusted so that the inlet total pressure loss appeared the same for the W8 inlet as for the flight-like $9 \times 15$ inlet. The performance results shown later for W8 have this 1D correction included. The spanwise performance effect of this thicker inlet boundary layer is discussed in Appendix C.

\section{Exit Diffuser/Throttle Valve Geometry}

Flow in the W8 exit diffuser had a significant swirl velocity because testing was done with a rotor alone configuration. Problems with diffuser performance in previous fan tests were attributed to separated flow in the diffuser caused by exit fan swirl. To avoid this issue in W8, the exit diffuser was designed to accelerate the flow from the nozzle highlight to the throttle valve. This design prevents the swirling flow from separating and allowed the fan to be throttled smoothly over the entire operating range. However, the accelerating flow results in decreasing static pressure through the diffuser and altitude exhaust was required to achieve the full fan flow range.

\section{Mass Flow Measurement}

The 9x15 LSWT fan module uses wall static pressure measurements in the flight or bellmouth inlet to determine mass flow through the model. The W8 has previously always used an orifice plate in the inlet piping on the test cell roof. Orifice plates are simple, rugged, and have \pm 1.0 percent of reading accuracy as a means to determine mass flow (Ref. 8). However, the pressure drop associated with the orifice plate is high compared to a flow nozzle or venturi. At the design speed flow rate the pressure drop across the orifice plate is $11.4 \mathrm{kPa}$ (1.6 psi), thus the pressure in the inlet plenum is subatmospheric. For much of the fan operating map the low static pressure rise of the fan followed by the static pressure drop through the exit diffuser results in sub-atmospheric pressure at the throttle valve. To define the full fan map, altitude exhaust was used to reduce the back pressure on the throttle valve. This is a more costly and operationally complex mode in which to run the facility. To remedy this a different mass flow measurement technique was implemented.

A Navier-Stokes calculation of portions of the W8 plenum, the inlet bellmouth and fan flow path up to the fan face was done to find a suitable location for wall static taps and to determine a mass flow rate correlation to wall static pressure. The fan was modeled as a piecewise constant radial exit static pressure boundary condition. The inlet boundary condition had total conditions specified with the measured plenum total pressure boundary layer included. A series of flow rates which bracketed the test conditions were simulated and a correlation for corrected mass flow as a function of wall static pressure was developed from the simulation data. For a fixed set of reference conditions (standard day in this case) corrected flow is only a function of static pressure (Ref. 9). More details regarding the mass flow rate correlation are in Appendix A.

Tests were conducted with the orifice plate and wall static pressure taps installed concurrently to verify the method. The orifice plate was then removed. Without the orifice pressure drop it was possible to map the sea level static, fixed nozzle operating line for the fan using only atmospheric exhaust blowers. More detail of fan testing with altitude and atmospheric exhaust is contained in Appendix A.

\section{9x15 LSWT to W8 Aeroperformance Comparison}

The instrumentation and measurement accuracy is described first. Aeroperformance comparisons begin with fan maps to demonstrate overall agreement for the three fan speeds which were tested in detail. Only a small subset of the measurements database is presented here. Results from the 100 percent Nc fixed nozzle operating line point are shown in greater detail with radial profiles of pressure ratio and fan wake surveys of turbulence intensity.

\section{W8 Instrumentation}

Fan inlet conditions were determined from four total pressure/total temperature probes located in the inlet plenum. Fan performance was determined using three fixed total pressure and three fixed total temperature rakes each with seven elements spaced at the center of equal areas. Wall mounted statics were also located at several locations through the fan flowpath so that internal velocities could be determined. Fan mass flow rate was determined using an orifice plate or inlet wall static pressure as described earlier. Spanwise surveys of total pressure were done with a traversing cobra probe.

\section{W8 Measurement Uncertainty}

Uncertainties given below are representative of the W8 data acquisition system as configured in 2005. The pressure measurement system accuracy was $\pm 34.5 \mathrm{~Pa}(0.005 \mathrm{psi})$ for the inlet probes and $\pm 55.2 \mathrm{~Pa}(0.008 \mathrm{psi})$ for the exit rakes and survey probe. The accuracy of the W8 temperature measurement system was limited primarily by the reference block temperature measurement accuracy, the A/D system 
accuracy, and knowledge of thermocouple wire corrections. The use of correlated thermocouples or wire corrections increases the sensor accuracy to $\pm 0.1^{\circ} \mathrm{C}\left(0.2^{\circ} \mathrm{F}\right)$. In W8 the plenum probe thermocouples had wire corrections applied. The thermocouple rakes were correlated with reference platinum thermocouples and had a correction applied based on those correlations. With calibrated thermocouples the temperature measurement system accuracy is $\pm 0.7^{\circ} \mathrm{C}\left(1.2^{\circ} \mathrm{F}\right)$ including reference block and $\mathrm{A} / \mathrm{D}$ uncertainties. The above accuracies and the resulting uncertainty bands in Table 6 represent 'worst case' values. Operational experience and empirical observations indicate that the data system accuracy for determining the absolute pressure and temperature values is better than the above analysis would suggest. To reduce random errors, the data system is configured so that temperature and pressure values are the average of five readings taken $1 \mathrm{sec}$ apart. Relative comparisons between configurations when using the same data system and instrumentation will also be more accurate since any bias errors are consistent. The orifice plate mass flow measurement accuracy is \pm 1.0 percent as mentioned earlier. The ability to reset operating point was not considered in the above analysis. Measurement uncertainties for the 9x15 SDT test data are given in Reference 1.

TABLE 6.-AEROPERFORMANCE UNCERTAINTIES FOR THE FIXED NOZZLE OPERATING POINTS IN W8

\begin{tabular}{|c|c|c|c|}
\hline $\begin{array}{c}\text { Speed, } \\
\% \mathrm{Nc}\end{array}$ & $\begin{array}{c}\text { Pressure } \\
\text { rise, } \\
\%\end{array}$ & $\begin{array}{c}\text { Temperature } \\
\text { rise, } \\
\%\end{array}$ & $\begin{array}{c}\text { Adiabatic } \\
\text { efficiency, } \\
\%\end{array}$ \\
\hline 61.7 & \pm 1.2 & \pm 21 & \pm 10 \\
87.5 & \pm 0.5 & \pm 10 & \pm 4.5 \\
100 & \pm 0.4 & \pm 7 & \pm 3.5 \\
\hline
\end{tabular}

\section{Fan Map Comparisons}

Of the fan blade/hub combinations tested, data from the $9 \times 15$ blades $+9 \times 15$ hub provides the most direct comparison of aeroperformance from the $9 \times 15$ and W8. Additional comparisons of other hub/blade combinations for 100 percent Nc speedline are in the appendix. Figures 8, 9 and 10 show the fan maps of pressure ratio, temperature ratio and adiabatic efficiency as derived from area averaged rake measurements.

The minimum flow points for each 9x15 speedline represent the lowest flow rate operating points for which blade stresses are acceptable. The fan blades were not strain gaged for the testing in W8 so a flow margin above the $9 \times 15$ minimum flow was always maintained to avoid any chance of inducing high blade stresses or stalling the fan.

Figure 8 shows good overall agreement in terms of pressure rise. A detailed comparison of the fixed nozzle operating line points is tabulated in Table 7. At 100 percent Nc the rotor performance agrees with the $9 \times 15$ measurements to better than 0.5 percent. The most noticeable difference is a change in choke flow of +0.8 percent on the 100 percent Nc speedline. A similar shift in choke flow is apparent for the 87.5 percent $\mathrm{Nc}$ speedline as well. The trend of higher choke flow is consistent and is also shown by the alternate mass flow measurement method shown in Figure 14, Appendix A. The magnitude of the difference ( 0.8 percent) is within the uncertainty band (1.0 percent) of the measurement so no definitive conclusion can be drawn as to whether the change in choke flow is real or due to a bias error in flow measurement. The goal of pressure rise and flow rate agreement between W8 and the 9x15 test to better than 1 percent was achieved.

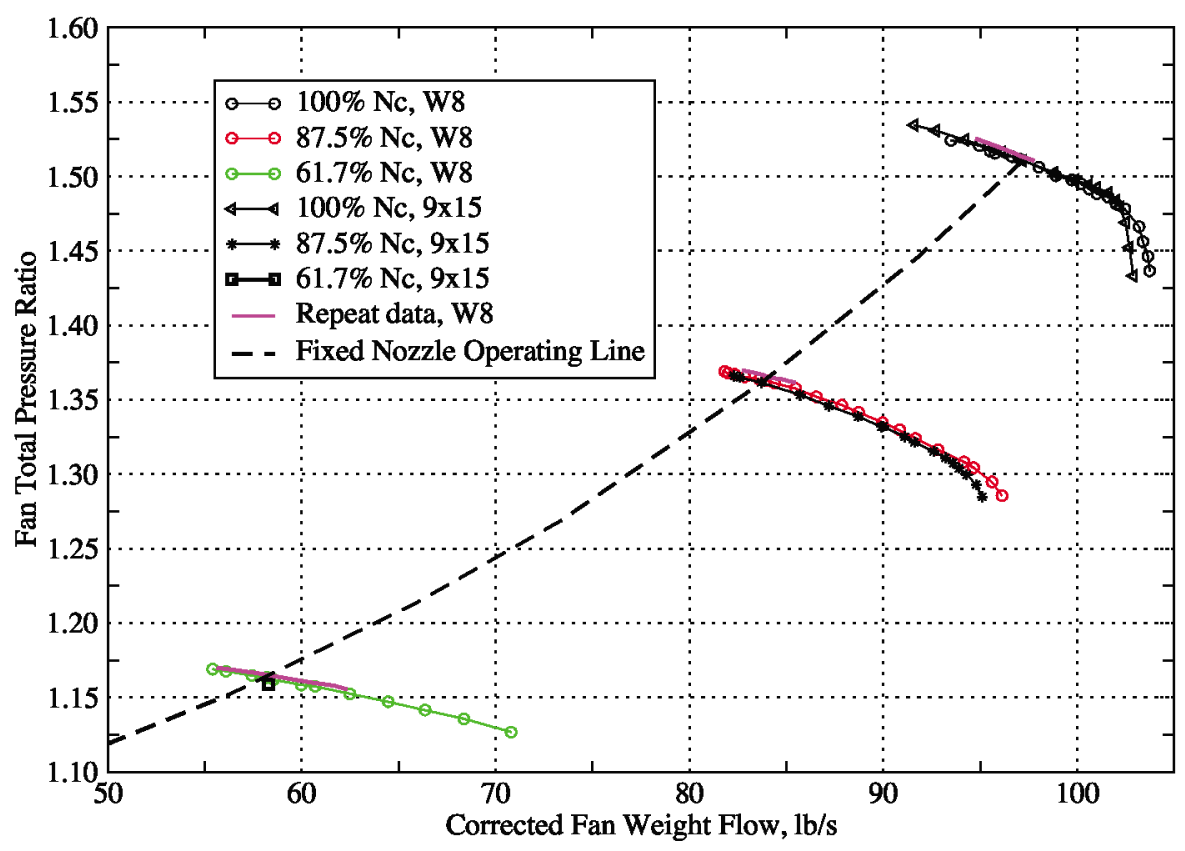

Figure 8.-Comparison of $\mathbf{W} 8$ and $9 \times 15$ fan pressure ratio maps. 


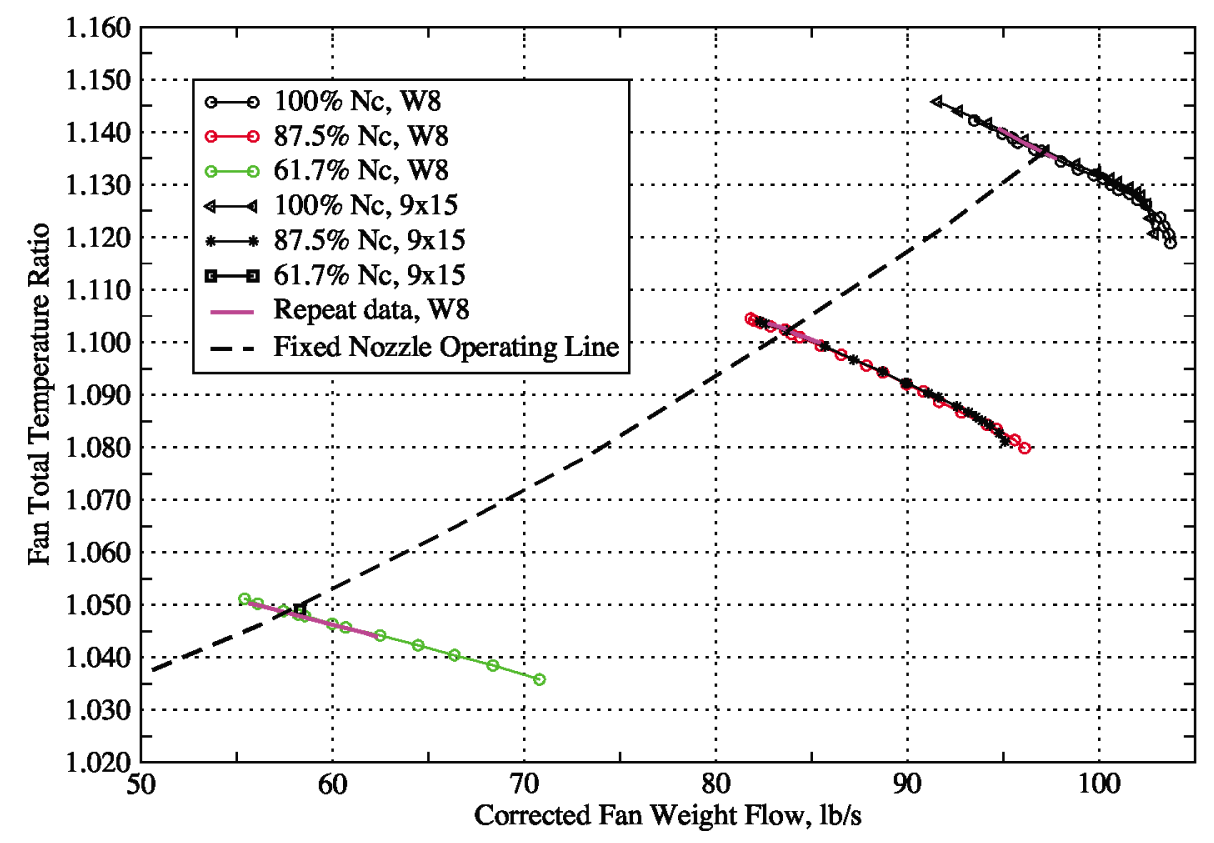

Figure 9.-Comparison of W8 and $9 \times 15$ fan temperature ratio maps.

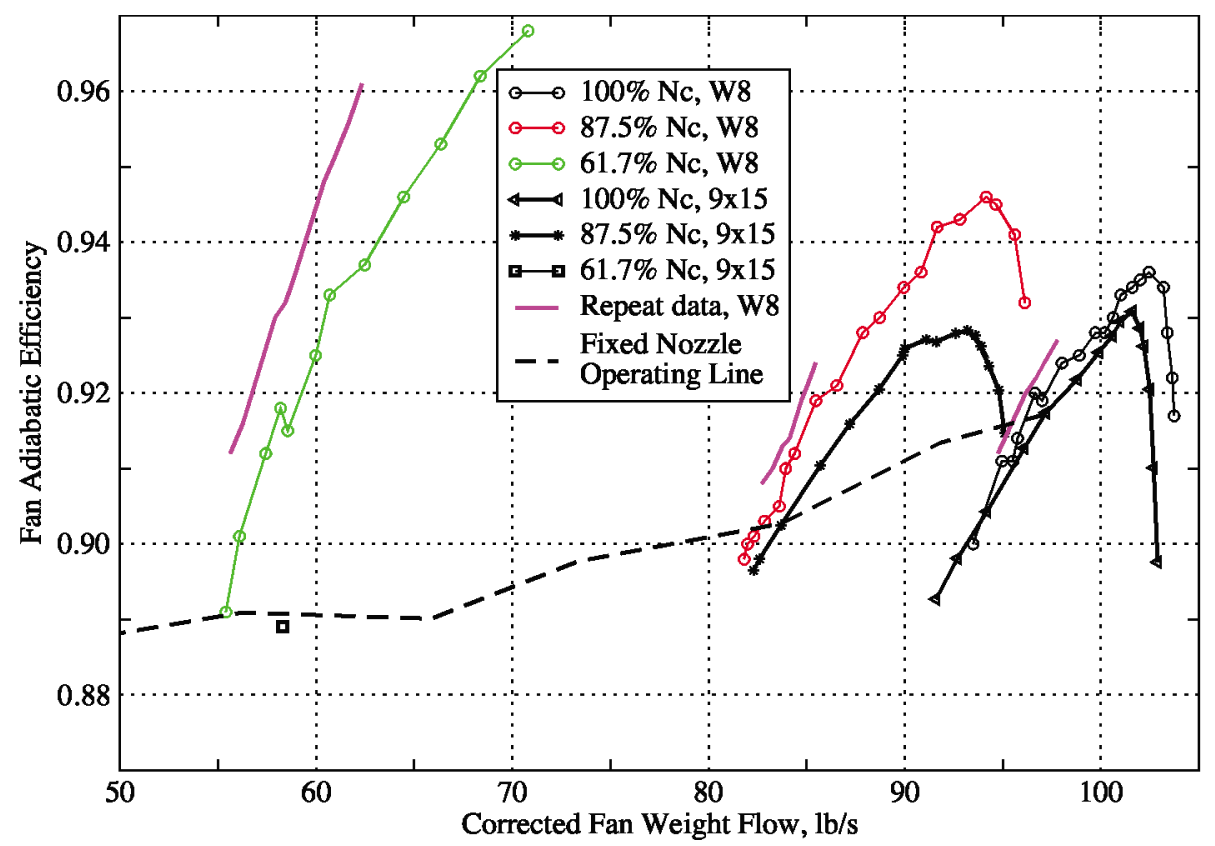

Figure 10.-Comparison of W8 and 9x15 fan adiabatic efficiency maps.

TABLE 7.-FIXED NOZZLE OPERATING LINE AEROPERFORMANCE COMPARISON

[The $9 \times 15$ data is the baseline]

\begin{tabular}{|c|c|c|c|c|}
\hline $\begin{array}{c}\text { Speed, } \\
\% \mathrm{Nc}\end{array}$ & $\begin{array}{c}\Delta \text { choke } \\
\text { flow, } \\
\%\end{array}$ & $\begin{array}{c}\Delta \text { pressure } \\
\text { rise, } \\
\%\end{array}$ & $\begin{array}{c}\Delta \text { temperature } \\
\text { rise, } \\
\%\end{array}$ & $\begin{array}{c}\Delta \text { adiabatic } \\
\text { efficiency, } \\
\%\end{array}$ \\
\hline 61.7 & N/A & 3.0 & -0.4 & 2.6 \\
87.5 & N/A & 0.6 & 0.3 & 0.3 \\
100 & 0.8 & 0.3 & 0.0 & 0.2 \\
\hline
\end{tabular}

Temperature ratio comparisons, Figure 9, are in reasonable agreement on an overall basis. However, small differences in temperature rise and pressure rise are compounded when adiabatic efficiency is computed, as shown in Figure 10. The adiabatic efficiency agreement is within 1.0 percent for the 100 percent Nc speedline. The agreement is fair for the 87.5 percent Nc speedline with the maximum difference of 2 percent. The 61.7 percent Nc speedline shows poor 
agreement with the $9 \times 15$ fixed nozzle data. At low pressure ratio and temperature ratio the measurement uncertainties for the data systems used for the test are quite large and poor measurement agreement and repeatability can be expected. Refinements to the temperature measurement system accuracy are ongoing and expected to reduce temperature measurement uncertainties by more than 50 percent for future tests which will include even lower pressure rise fans.

\section{Spanwise Profiles}

Spanwise profiles of pressure ratio and adiabatic efficiency for the 100 percent Nc fixed nozzle operating point are shown in Figure 11. The average of the three total pressure rakes is shown and are compared to an average radial profile from the $9 \times 15$ test. Agreement of the average rake profiles is within 2 percent of pressure rise at all spanwise locations. The differences seen are on the order of the rake-to-rake data scatter. Spanwise profiles of adiabatic efficiency show a decreased efficiency in the outer 30 percent span region for W8 and an increased efficiency at lower spans. This trend is consistent with a spanwise redistribution of flow due to a thicker casing boundary layer but the magnitude of the difference is too large for a flow redistribution to be solely responsible. The differences are well within measurement uncertainties so no definitive conclusion can be drawn. Further detail of the effect of casing boundary layer thickness on radial profiles is shown in Appendix C.

\section{Fan Wake Turbulence}

Finally, fan exit hot film measurements were acquired to compare turbulence intensity and fan wake profiles. Figure 12 shows overall turbulence intensity results. The overall wake width, turbulence intensity and casing boundary layer turbulence character show good agreement between the facilities. Figure 13 shows 77 percent span values. For W8, two separate hot film surveys are shown where a yaw probe is sensitive to axial and tangential velocities and a pitch probe is sensitive to axial and radial velocities. Figure 13 shows that the fan exit core flow turbulence intensity for the $9 \times 15$ fan module is 0.75 percent based on 3-component hot film measurements. From a 9x15 fan module inlet turbulence intensity of 0.25 percent (Refs. 10 and 11), this is an increase of 0.5 percent in the core flow turbulence by passing through the fan rotor. For W8 the fan inlet turbulence intensity is 0.8 percent with a core flow turbulence of 1.5 percent after passing through the fan rotor, an increase of 0.7 percent. The increase of 0.7 percent in core flow turbulence in the W8 test is consistent with what would be expected based on the $9 \times 15$ results.
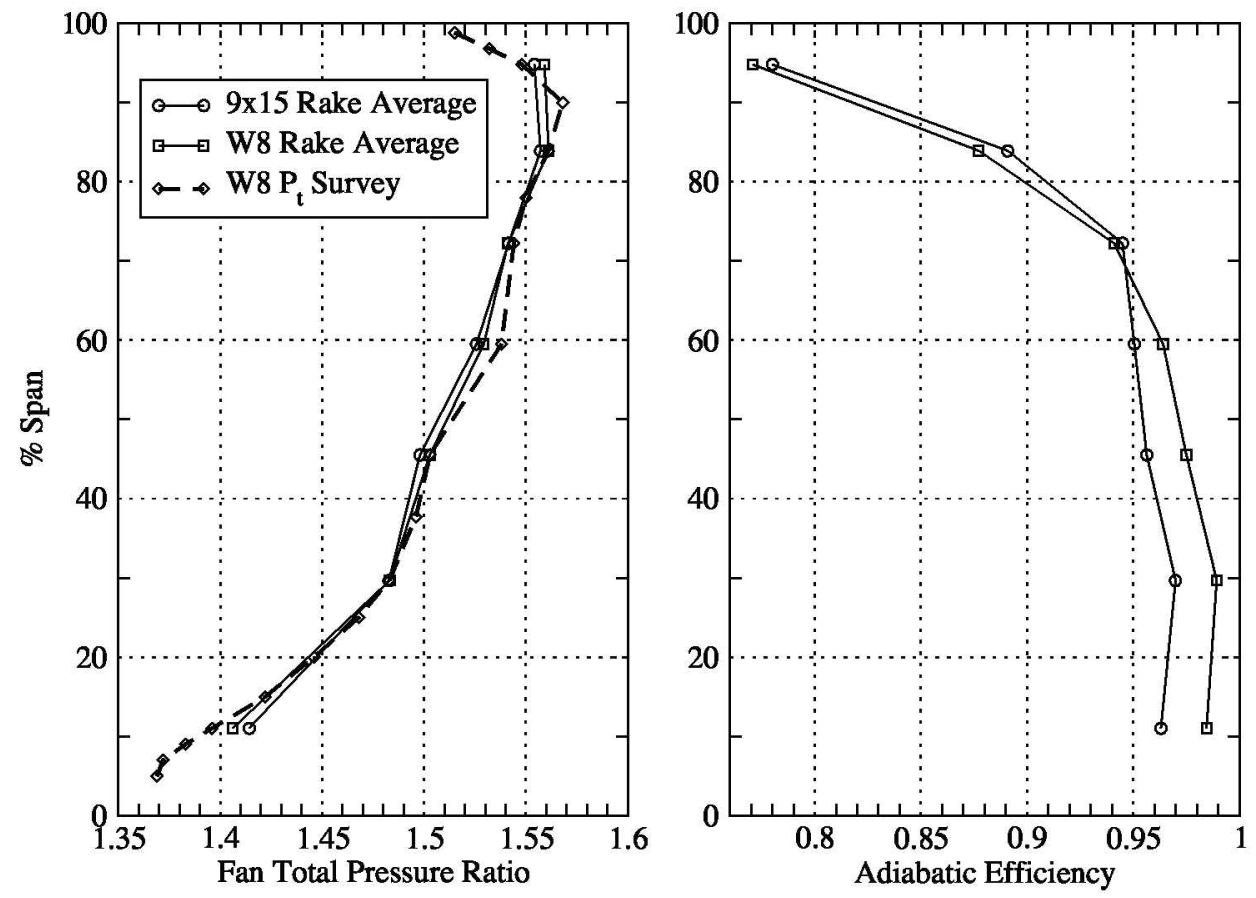

Figure 11.-Radial profiles of total pressure and adiabatic efficiency for the 100 percent Nc fixed nozzle operating point. 

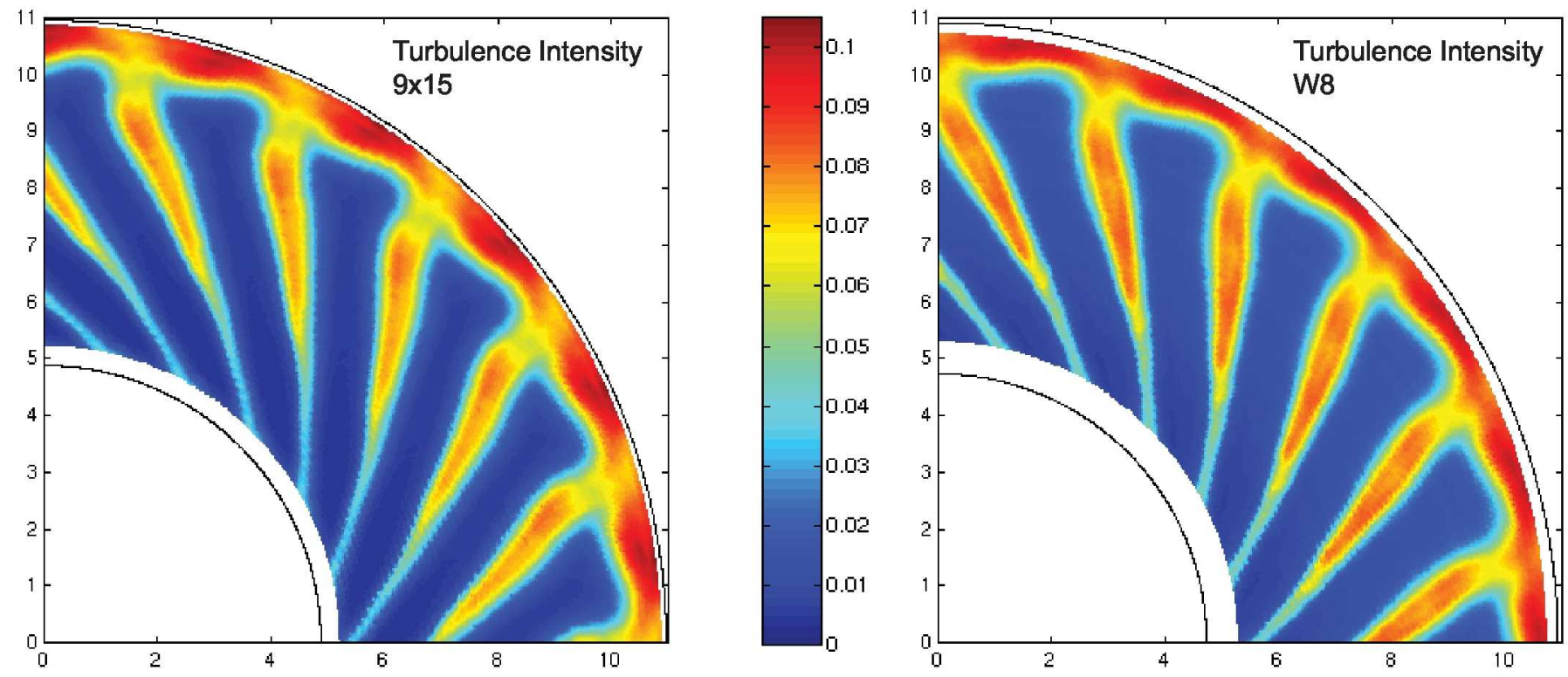

Figure 12.-Comparison of fan wake turbulence intensity.

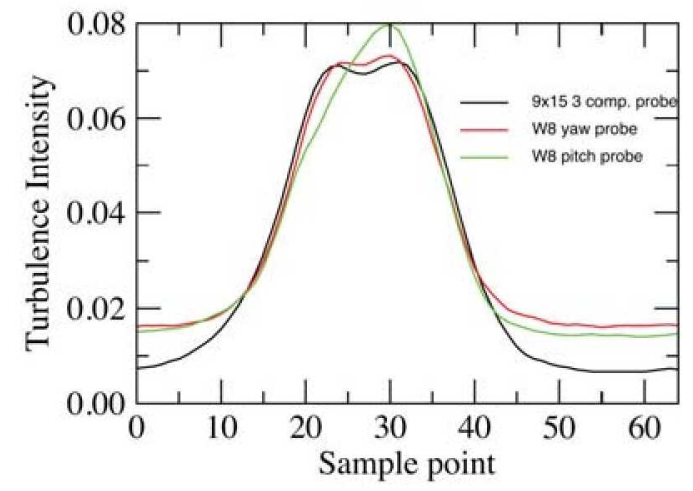

Figure 13.-Fan wake turbulence comparison at 77 percent span. One rotor blade pitch is shown.

\section{Discussion}

It is challenging to achieve low free stream turbulence intensity and a thin casing boundary layer in an internal flow facility like W8. Upgrades to the W8 inlet plenum significantly improved the facility flow quality. The flow turbulence intensity at the fan face is low enough to be considered representative of the $9 \times 15$. Further improvements to casing bleed system are needed to allow higher bleed flow rates to fully achieve a casing boundary layer thickness which is representative of the $9 \times 15$.

The flow range for high flow, low pressure rise fans is restricted due to piping pressure losses in internal flow facilities if other measures are not taken to offset the pressure drops. In this class of fans flow rises quickly with speed but static pressure ratio does not. When using high pressure drop mass flow measurement devices, such as an orifice plate, the fan exit pressure can be sub-atmospheric and altitude exhaust is required for fan operation. A partial solution to the issue was use of an inlet wall static pressure correlation to determine mass flow. This allowed operation of the fan on the fixed nozzle operating line while using atmospheric exhaust which is the preferred operating configuration.

Continued data system accuracy improvements are needed, especially for the temperature measurement system. Upgrades of the thermocouple reference blocks will reduce uncertainty to $\pm 0.4{ }^{\circ} \mathrm{C}\left(0.7{ }^{\circ} \mathrm{F}\right)$, but even more precise temperature measurements will be necessary to meet the desired adiabatic efficiency accuracy. We are nearing the limits of thermocouple measurement accuracy. Further improvements may require a change in sensor type (thermistors, for example) or method (torque based efficiency).

A central question of this research study is "How close is close enough?" In other words, how similar must the aeroperformance and turbulence environments of W8 be to the $9 \times 15$ for the W8 facility to be a viable noise source diagnostics facility. Comparisons of flow and pressure rise show good agreement and refinements to the casing boundary layer bleed system will further improve the similarity. The technique of Nallasamy (Ref. 12) was used to calculate the increase in broadband noise that would be expected due to a core flow turbulence intensity increase from 0.75 to 1.5 percent. A prediction for the approach operating condition showed an increase of $\sim 5 \mathrm{~dB}$ for frequencies between $1 \mathrm{kHz}$ and $48 \mathrm{kHz}$. The higher inflow turbulence could swamp the effect of geometry changes in a raised background noise floor. Fortunately Figure 13 shows that wake turbulence and 
presumably turbulence from other significant broadband noise sources is well above the background turbulence level. Identification of noise sources by aerodynamic means instead of acoustic response is still viable in W8.

\section{Conclusions}

The aerodynamic qualities of the W8 internal flow, component test facility were upgraded to allow testing of fan rotors in a flow environment that is representative of a fan module installation in the 9x15 LSWT. Inlet flow conditioning was added that reduced inflow turbulence intensity at the rotor plane to less than 1 percent. Casing boundary layer bleed capability was incorporated into the fan flowpath to make the casing boundary layer more representative of a flight-type nacelle boundary layer. The Source Diagnostics Test fan rotor was installed and tested in the upgraded facility. Overall flow and pressure rise for the rotor at Takeoff, Cutback and Approach operating speeds agreed to within 1 percent of data acquired previously from a fan module installed in the $9 \times 15$ LSWT. Comparisons of rake profiles of pressure ratio further confirm the fan flowfield similarity between the W8 and $9 \times 15$ test package installations. W8 has an increased core flow turbulence intensity compared to the $9 \times 15$. However, in W8, the wake turbulence and presumably turbulence from other significant broadband noise sources is still well above the background turbulence level.

\section{References}

1. Hughes, Christopher E., "Aerodynamic Performance of ScaleModel Turbofan Outlet Guide Vanes Designed for Low Noise," AIAA-2002-0374 or NASA/TM-2001-211352.
2. Hughes, Christopher E., Jeracki, Robert J., Woodward, Richard P., and Miller, Christopher J., "Fan Noise Source Diagnostic TestRotor Alone Aerodynamic Performance Results," AIAA-20022426, AIAA Aeroacoustics Conference, Breckenridge, CO, Jun. 17$19,2002$.

3. Strazisar, A.J., Wood, J.R., Hathaway, M.D., and Suder, K.L., "Laser Anemometer Measurements in a Transonic Axial-Flow Fan Rotor," NASA TP-2879, 1989.

4. Denton, J.D., "Lessons Leamed from Rotor 37," presented at the $3^{\text {rd }}$ International Symposium on Experimental and Computational Aerothermodynamics of Internal Flows (ISAIF), Beijing, China, Sep. 1-6, 1996.

5. Burley, Richard R. and Harrington, Douglas E., "Experimental Evaluation of Honeycomb/Screen Configurations and Short Contraction Section for NASA Lewis Research Center's Altitude Wind Tunnel," NASA TP-2692, 1987.

6. Porro, A.R., Hingst, W.R., Wasserbauer, C.A., and Andrews, T.B., "The NASA Lewis Research Center Internal Fluid Mechanics Facility,"NASA TM-105187, 1991.

7. Loehrke, R.I. and Nagib, H.M., "Control of Free Stream Turbulence by Means of Honeycombs: A Balance Between Suppression and Generation," ASME 76-FE-2, presented at the Gas Turbine and Fluids Engineering Conference, New Orleans, LA, Mar. 21-25, 1976.

8. Bean, Howard S. editor, Fluid Meters, ASME, New York, 1971.

9. Mattingly, Jack D., Elements of Gas Turbine Propulsion, Mc-GrawHill, Inc., New York, 1996.

10. Arrington, A.E., and Gonsalez, J.C., "Flow Quality Improvements in the NASA Lewis Research Center 9- by 15-Foot Low Speed Wind Tunnel," NASA CR-195439, 1995.

11. Dahl, M.D. and Woodward, R.P., "Acoustical Evaluation of the NASA Lewis 9- by 15-Foot Low Speed Wind Tunnel," NASA TP3274, 1992.

12. Nallasamy, M. and Envia, E., "Computation of Rotor Wake Turbulence Noise," Journal of Sound and Vibration, Vol. 282, 2005.

13. Panek, Joseph, private communication. 



\section{Appendix A-Comparison of Altitude and Atmospheric Exhaust Fan Maps}

The preferred testing configuration for $\mathrm{W} 8$ is atmospheric inlet and atmospheric exhaust. This reduces testing cost and reduces operational complexity compared to using altitude exhaust. The use of an orifice plate for flow rate measurement with its associated pressure drop required the use of altitude exhaust to operate the SDT fan. An alternative flow rate measurement method was developed and the flow range for the fan determined for the atmospheric exhaust configuration.

Wall static pressure taps were added to the constant area section of the W8 inlet duct upstream of the throat. A correlation of corrected mass flow rate versus wall static pressure was developed using results from a numerical simulation of the flow in the $\mathrm{W} 8$ inlet. The wall static flow correlation included a grid study, the effect of bleed rate (at the slot downstream of the static tap), and the effect of using the Baldwin-Lomax versus Spalart-Allmaras turbulence models, in an attempt to remove as many computational uncertainties as possible. Once grid resolved, a number of calibration curve fits were evaluated. The best fit was a third order polynomial to a flowrate-like parameter, $\rho\left(P_{s} / P\right.$ total $) * \operatorname{Mach}\left(P_{s} / P_{\text {total }}\right):$

$$
W F c(x)=A+B^{*} f(x)+C^{*} f(x)^{2}+D^{*} f(x)^{3}
$$

$$
\begin{aligned}
& x=P_{S} / P \text { total } \\
& f(x)=\rho(x)^{*} M(x)=x^{5 / 7} * \sqrt{5 *\left(x^{-2 / 7}-1\right)}
\end{aligned}
$$

The resulting correlation is shown in Figure 14.

At the highest flow rate, $-46 \mathrm{~kg} / \mathrm{s}$, the accuracy of the fit is very good: $\left|W F c_{C F D}-W F c_{f i t}\right| \leq 0.02 \mathrm{~kg} / \mathrm{s}(0.04$ percent of flow). As the flow rate decreases the scatter between CFD solutions increases slightly. Because the flow rate is decreasing, the relative accuracy of the fit decreases. At $27 \mathrm{~kg} / \mathrm{s}$ the flow calculated from the various solutions fall within $0.045 \mathrm{~kg} / \mathrm{s}(0.2$ percent of flow), at $18 \mathrm{~kg} / \mathrm{s}$ the solutions are within $0.05 \mathrm{~kg} / \mathrm{s}(0.3$ percent of flow), and finally at the lowest flow rate, $14 \mathrm{~kg} / \mathrm{s}$, the solutions fall within $0.2 \mathrm{~kg} / \mathrm{s}$ (1.5 percent of flow). At this lowest flow there was one outlying solution; removing that solution puts the scatter under $0.08 \mathrm{~kg} / \mathrm{s}(0.6$ percent of flow $)$. In the region of interest for this study, 27 to $45 \mathrm{~kg} / \mathrm{s}$, the accuracy of the fit is better than $0.045 \mathrm{~kg} / \mathrm{s}$. The calibration fit can be used to evaluate the effect of static pressure sensor precision on the precision of calculated flow rate (see Fig. 14). The pressure sensor used for the W8 test had a precision of $\pm 34 \mathrm{~Pa}(0.005 \mathrm{psi})$ which results in an uncertainty of $\pm 0.07 \mathrm{~kg} / \mathrm{s}$ at $17 \mathrm{~kg} / \mathrm{s}$ flow rate and $0.04 \mathrm{~kg} / \mathrm{s}$ at $45 \mathrm{~kg} / \mathrm{s}$ flow rate.

where

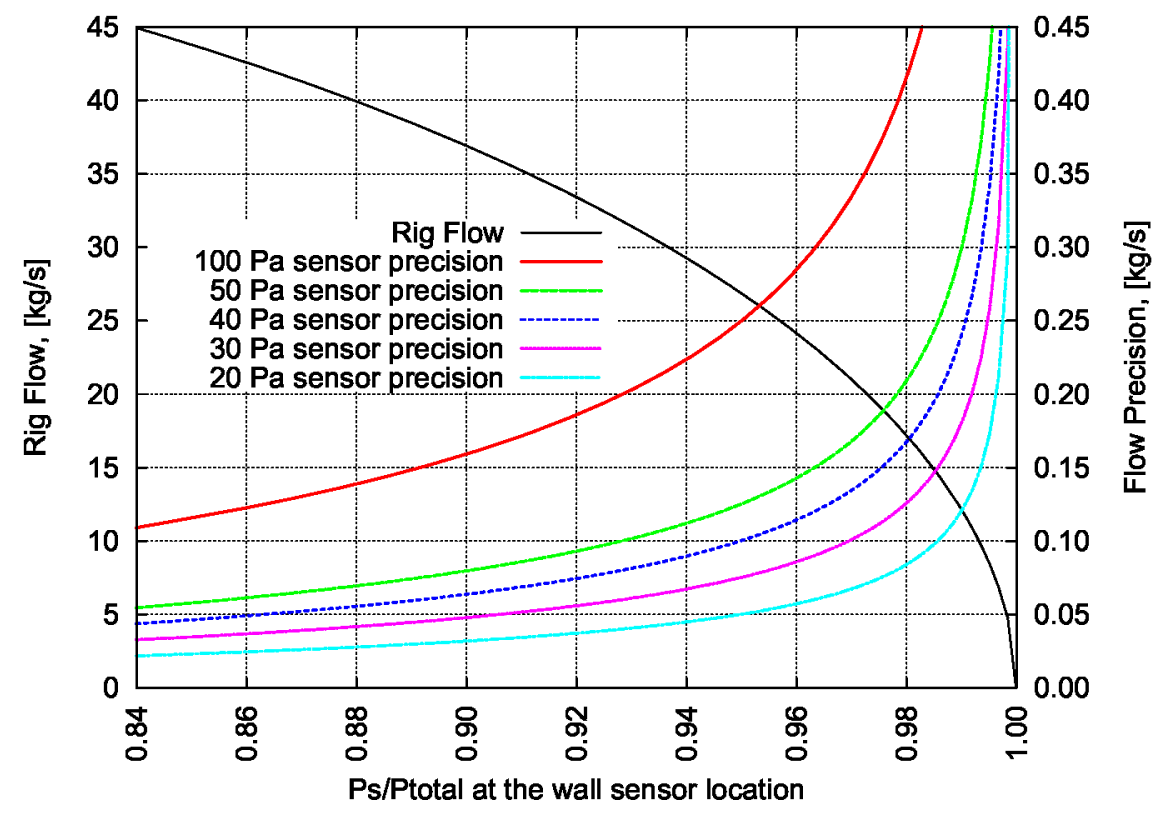

Figure 14.-W8 inlet wall static pressure mass flow rate correlation and sensor precision requirement. 


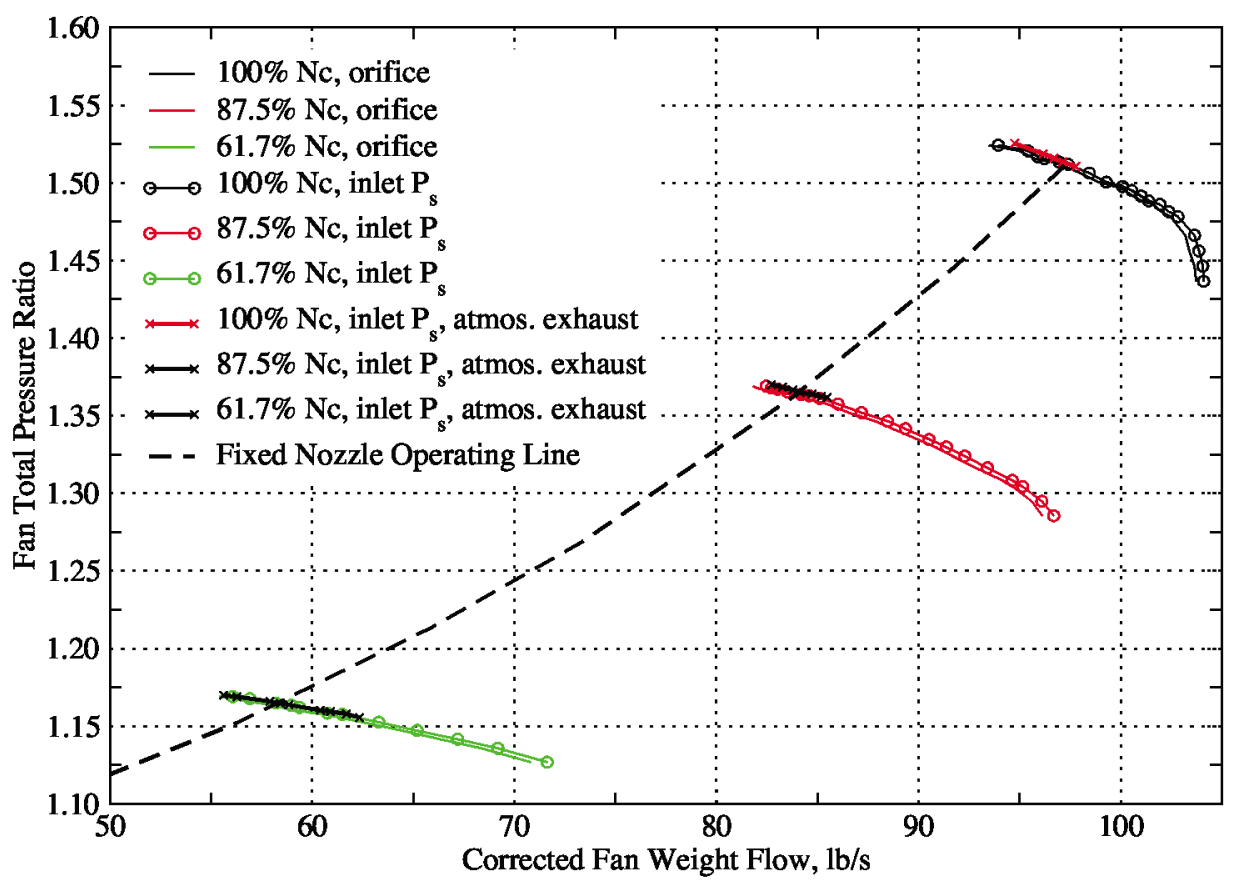

Figure 15.-Comparison of fan map with altitude and atmospheric exhaust.

To verify this correlation, data were acquired with the orifice plate and wall statics concurrently. Figure 15 shows speedline comparisons which show directly mass flow rate computed from orifice plate measurements and computed from casing wall statics. The 100 percent Nc choke flow rate is 0.4 percent higher than the orifice plate flow measurement. Agreement of the two independently flow rate measurement methods is excellent and is well within orifice plate measurement uncertainty.

With the measurement method verified, the orifice plate was removed and fan performance and flow range determined now using atmospheric exhaust. The speedline data for atmospheric exhaust are overlaid with the speedlines for altitude exhaust in Figure 15. The pressure ratio results for the atmospheric exhaust case are identical to the altitude exhaust results. The fan was able to operate along the fixed nozzle operating line and thus verified that detailed fan flow diagnostics could be performed at the fixed nozzle operating points when using atmospheric exhaust. However, the fan flow range is limited due to the exhaust duct design where the flow is continuously accelerated to the throttle sleeve. This exhaust duct design was necessary to keep the high swirl fan exit flow from separating in the duct. Adding the fan outlet guide vanes would remove the swirl, increase static pressure rise and thus increase the flow range when using atmospheric exhaust. For rotor only applications, altitude exhaust will be necessary to achieve the full fan flow range. 


\section{Appendix B-Comparison of Aero-Performance With Different Hub and Blade Combinations}

A duplicate rotor hub and fan blades were manufactured for the W8 test. The W8 hub was built to the original drawings with the exception of the dovetail slot. The 9x15 blades had a very 'loose' fit into the hub dovetail slot. Research rotors, such as NASA Fan 67 , normally have tight dovetail fits such that a mallet is needed to tap the blades into the slots. This allows the research rotors to be low speed balanced and also ensures that the blades always 'lock up' in the same position during testing. The W8 hub dovetail clearances were adjusted so that the blades had a tighter fit, but were still insertable by hand.

The original geometry for the R4 bladeset was no longer available. To manufacture the W8 bladeset a 9x15 fan blade was characterized with a coordinate measuring machine (CMM) and a manufacturing model built from the coordinates. Tolerances for the airfoil surfaces and blade edges matched the original blade drawing specifications.

Figure 16 shows the pressure ratio comparison for the 100 percent Nc speedline for the $9 \times 15$ blades in two different hubs and a comparison of the two bladesets in the same hub.
The design speed tip clearance height for the three configurations are given in Table 8 . Results for the $9 \times 15$ bladeset in two different hubs show pressure ratio and flow rate are nearly identical within measurement uncertainty (compare the black line to the green line in Fig. 15). A comparison of the two bladesets showed larger pressure ratio and flow differences, especially at the higher flow rates (compare the green line to the red line). This is an indication of manufacturing differences in trying to duplicate an existing blade geometry including changes in leading edge radius and tip clearance height.

TABLE 8.-100 PERCENT Nc AVERAGE TIP CLEARANCE HEIGHT

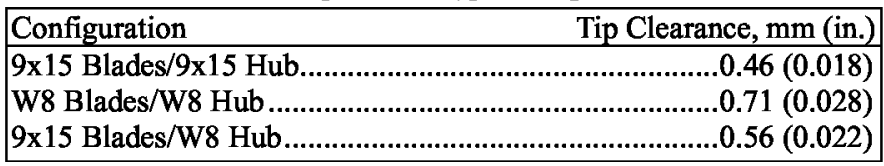

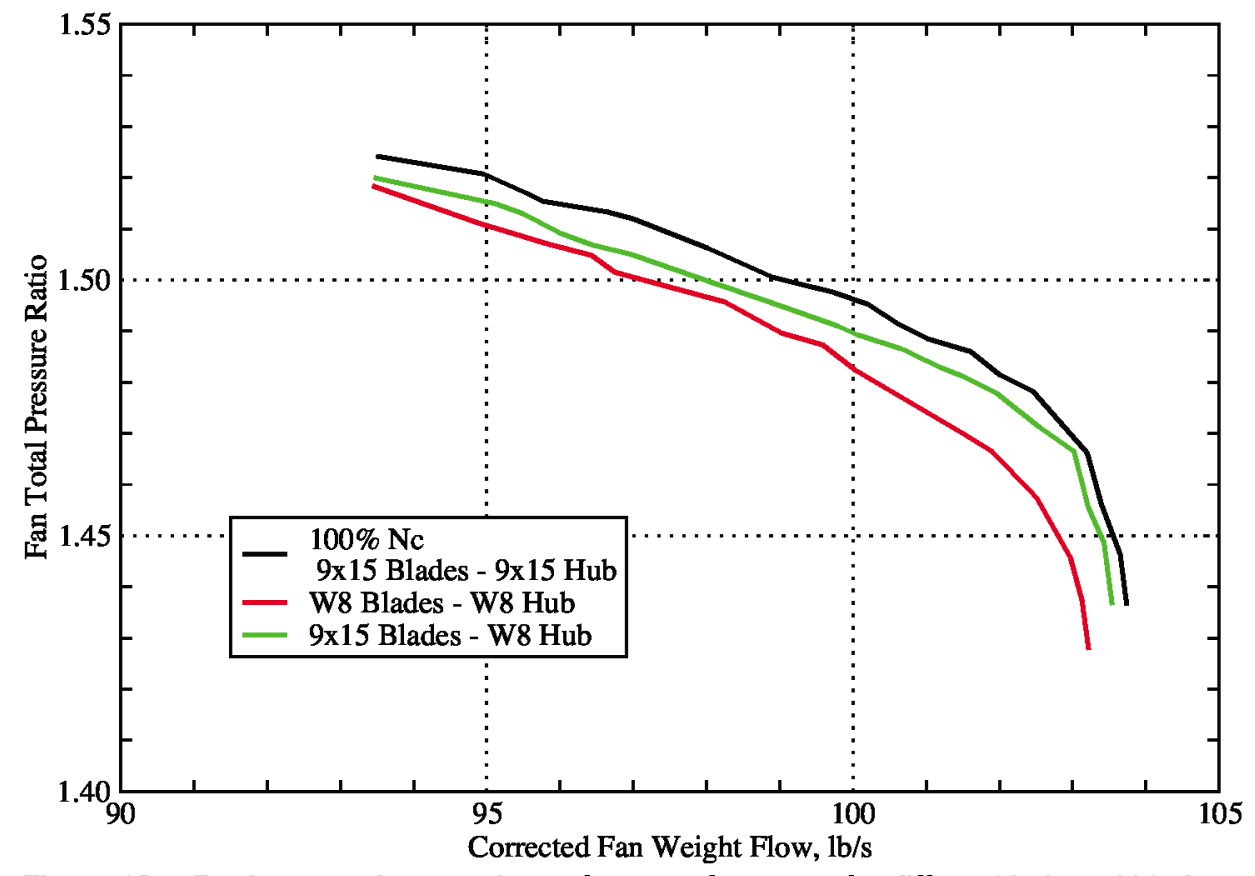

Figure 16.-Design speed comparison of aeroperformance for different hub and blade combinations. 



\section{Appendix C-Effect of Casing Boundary Layer Thickness on Rotor Performance}

The W8 boundary layer bleed system as configured in 2005 did not have sufficient flow capacity to thin the casing boundary layer to match the flight-like inlet boundary layer. Rotor performance measurements were at the same fan flow rate on the 100 percent Nc operating line with and without casing bleed flow. Overall performance for these operating points is given in Table 9.

Figure 17 shows spanwise profiles of pressure ratio with and without boundary layer bleed. Measurements of the casing boundary layer thickness are superimposed also. Pressure rise near the hub is identical but the outer spans show an increased pressure ratio with the thinner casing boundary layer. Thus the fan is sensitive to the inlet casing boundary layer thickness and the effect is measurable with the fan exit rakes. For the best match to the flight-like inlet the bleed system will require an upgrade to its flow capacity.

TABLE 9.-100 PERCENT Nc ROTOR PERFORMANCE WITH AND WITHOUT CASING BOUNDARY LAYER BLEED FLOW

\begin{tabular}{|l|c|c|c|c|}
\hline & $\begin{array}{c}\text { Fan Flow, } \\
\mathrm{kg} / \mathrm{s}\end{array}$ & $\begin{array}{c}\text { Pressure } \\
\text { ratio }\end{array}$ & $\begin{array}{c}\text { Temperature } \\
\text { ratio }\end{array}$ & $\begin{array}{c}\text { Adiabatic } \\
\text { efficiency }\end{array}$ \\
\hline Bleed $0.0 \mathrm{~kg} / \mathrm{s}$ & 43.8 & 1.501 & 1.135 & 0.909 \\
Bleed $0.54 \mathrm{~kg} / \mathrm{s}$ & 43.7 & 1.505 & 1.136 & 0.910 \\
\hline
\end{tabular}

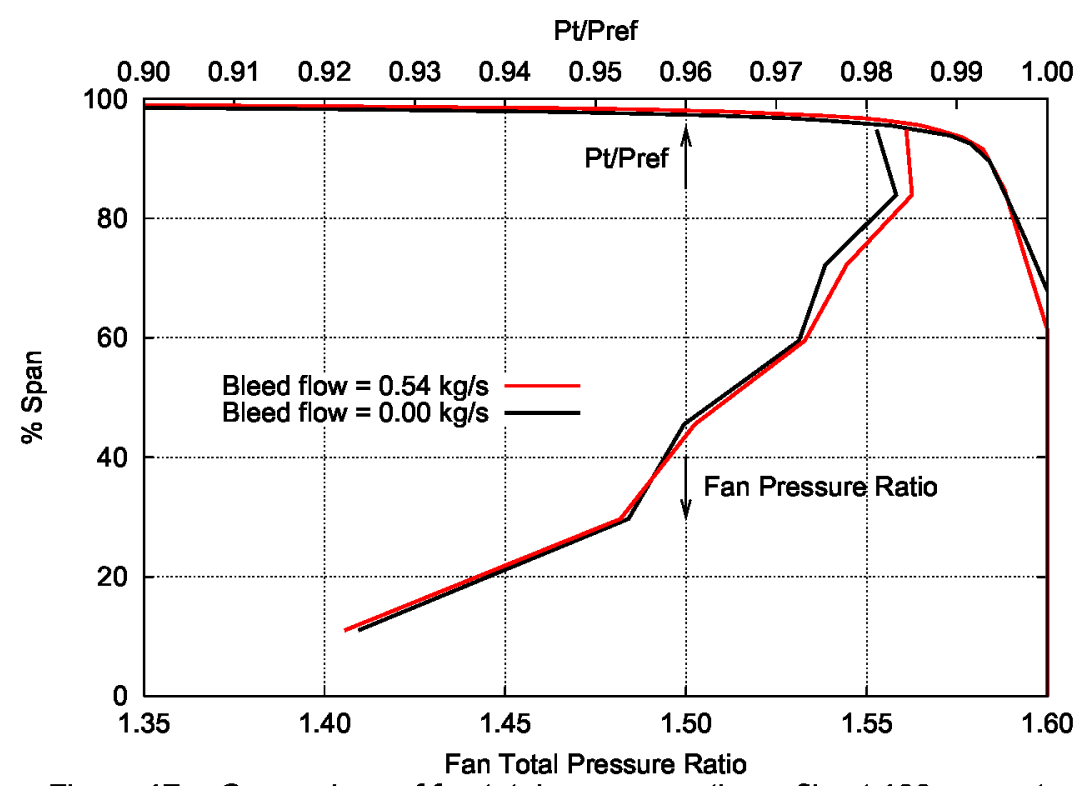

Figure 17.-Comparison of fan total pressure ratio profile at 100 percent Nc with and without inlet casing boundary layer bleed. Measured inlet casing boundary layer (Pt/Pref) is shown superimposed. 



\section{Appendix D-W8 Measurement Systems}

Measurement systems in use during 2005 and their associated uncertainties are listed in Table 10 (data from Ref. 13).

TABLE 10.-2005 W8 TEMPERATURE AND PRESSURE MEASUREMENT SYSTEMS ACCURACY

\begin{tabular}{|c|c|c|}
\hline \multirow[t]{2}{*}{ Temperature measurement system } & $\begin{array}{l}\text { Hycal Reference Block } \\
\text { Neff } 400 \text { digitizer } \\
\text { Thermocouple wire }\end{array}$ & $\begin{array}{l} \pm 0.6^{\circ} \mathrm{C}\left(1.0^{\circ} \mathrm{F}\right) \\
\pm 0.3^{\circ} \mathrm{C}\left(0.5^{\circ} \mathrm{F}\right) \\
\pm 0.1^{\circ} \mathrm{C}\left(0.2^{\circ} \mathrm{F}\right)\end{array}$ \\
\hline & $\begin{array}{rc}\text { TOTAL } \\
\end{array}$ & $\pm 0.7^{\circ} \mathrm{C}\left(1.2^{\circ} \mathrm{F}\right)$ \\
\hline Pressure measurement system & $\begin{array}{l}\text { Pressure Systems Inc. System } 8400 \\
5 \text { psi module } \\
15 \text { psi module }\end{array}$ & $\begin{array}{l} \pm 34 \mathrm{~Pa}(0.005 \mathrm{psi}) \\
\pm 55 \mathrm{~Pa}(0.008 \mathrm{psi})\end{array}$ \\
\hline
\end{tabular}




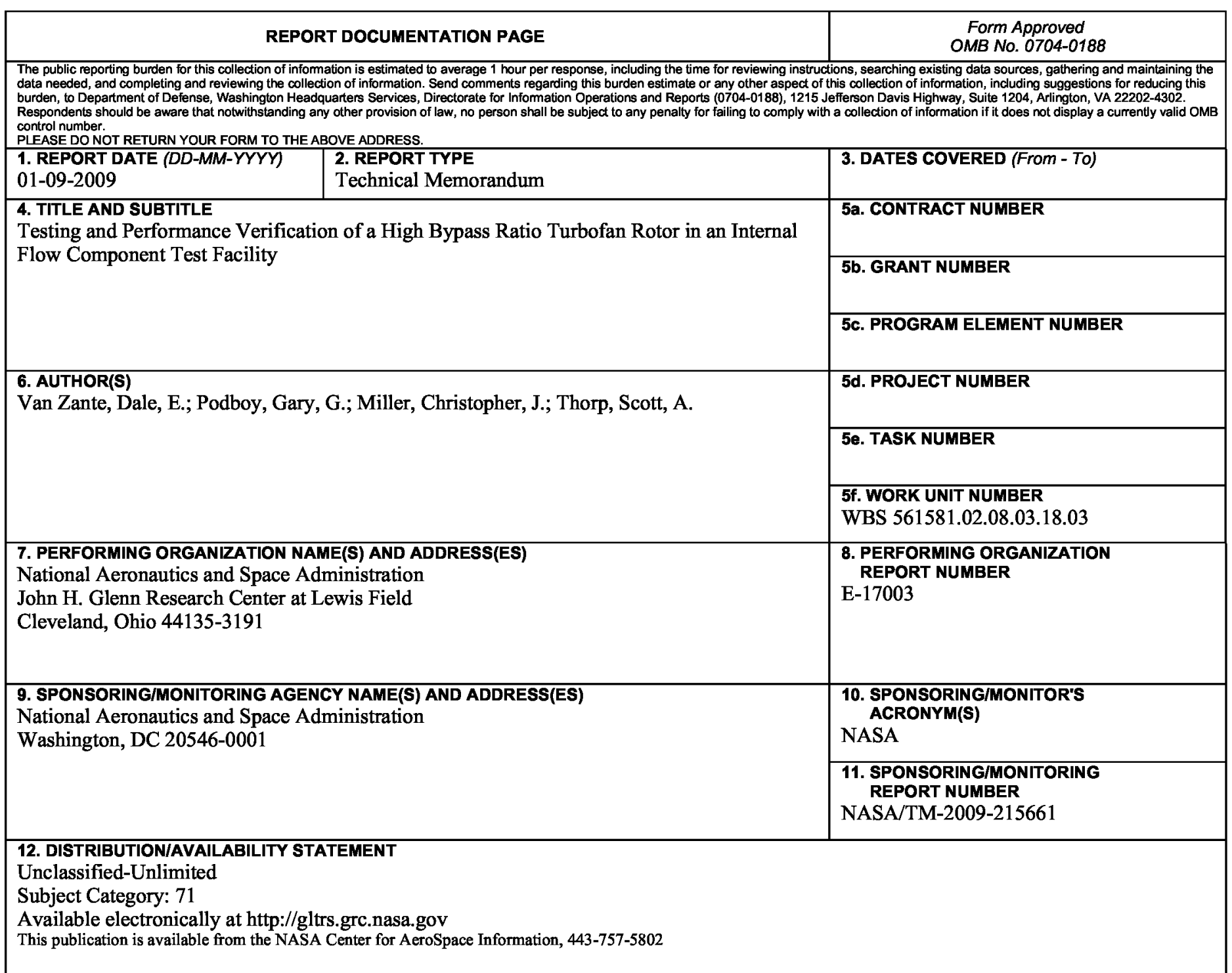

\section{SUPPLEMENTARY NOTES}

\section{ABSTRACT}

A $1 / 5$ scale model rotor representative of a current technology, high bypass ratio, turbofan engine was installed and tested in the W8 singlestage, high-speed, compressor test facility at NASA Glenn Research Center (GRC). The same fan rotor was tested previously in the GRC 9x15 Low Speed Wind Tunnel as a fan module consisting of the rotor and outlet guide vanes mounted in a flight-like nacelle. The W8 test verified that the aerodynamic performance and detailed flow field of the rotor as installed in W8 were representative of the wind tunnel fan module installation. Modifications to W8 were necessary to ensure that this internal flow facility would have a flow field at the test package that is representative of flow conditions in the wind tunnel installation. Inlet flow conditioning was designed and installed in W8 to lower the fan face turbulence intensity to less than 1.0 percent in order to better match the wind tunnel operating environment. Also, inlet bleed was added to thin the casing boundary layer to be more representative of a flight nacelle boundary layer. On the 100 percent speed operating line the fan pressure rise and mass flow rate agreed with the wind tunnel data to within 1 percent. Detailed hot film surveys of the inlet flow, inlet boundary layer and fan exit flow were compared to results from the wind tunnel. The effect of inlet casing boundary layer thickness on fan performance was quantified. Challenges and 'lessons learned' from testing this high flow, low static pressure rise fan in an internal flow facility are discussed.

\section{SUBJECT TERMS}

Fans; Turbofan engine; Rotor aerodynamics

\begin{tabular}{|l|l|l|l|l|l|}
\hline \multicolumn{2}{|l|}{ 16. SECURITY CLASSIFICATION OF: } & $\begin{array}{l}\text { 17. LIMITATION OF } \\
\text { ABSTRACT }\end{array}$ & $\begin{array}{l}\text { 18. NUMBER } \\
\text { OF } \\
\text { PAGES }\end{array}$ & $\begin{array}{l}\text { 19a. NAME OF RESPONSIBLE PERSON } \\
\text { STI Help Desk (email:help@sti.nasa.gov) }\end{array}$ \\
\cline { 1 - 1 } $\begin{array}{l}\text { a. REPORT } \\
\text { U }\end{array}$ & $\begin{array}{l}\text { b. ABSTRACT } \\
\text { U }\end{array}$ & $\begin{array}{l}\text { C. THIS } \\
\text { PAGE } \\
\text { U }\end{array}$ & UU & 22 & $\begin{array}{l}\text { 19b. TELEPHONE NUMBER (include area code) } \\
443-757-5802\end{array}$ \\
\hline
\end{tabular}



